\title{
The assessment of waters ecological state of the Crimea coastal near high-rise construction zones
}

\author{
Natalya Vetrova $^{1, *}$, Tatyana Ivanenko $^{1}$, and Emran Mannanov ${ }^{1}$ \\ ${ }^{1}$ Academy of Civil Engineering and Architecture of the Crimean Vernadsky Federal University, \\ 295493 Simferopol, Republic of Crimea
}

\begin{abstract}
The relevance of our study is determined by the significant level of coastal sea waters pollution by sewage near high-rise construction zones, which determines the violation of the sanitary and hygienic of sea waters "characteristics and limits the possibilities for organizing recreational activities. The purpose of this study is to identify the ecological state of the marine aquatic area by the example of the Western Crimea near high-rise construction zones. The studies confirmed that the recreational and coastal area wastewater is intensely mixed with seawater, as a result, the pollution in the coastal strip of the sea in the area of deep water discharges sharply decrease. This happens because of water rapid rise to the surface and under the influence of the continuous movement of sea water huge masses with deep-water discharge, fresh wastewater is actively mixed with sea water. However, with no doubt, it is inadmissible to discharge sewage into the sea directly from the shore, but only at the estimated distance from the coast. The materials of the article can be useful for the management bodies and organizations involved in monitoring the quality of the coastal zone of the sea, teachers and students of higher educational institutions when assessing the ecological situation of the territories.
\end{abstract}

\section{Introduction}

The sea is an important resort and recreational resource of the Crimea. In the coastal zone of the Western Crimea territory is a strip of relative shallow water (depths up to $20 \mathrm{~m}$ ), at the same time, the coastline length from the city of Sevastopol to the city of Evpatoria is about $75 \mathrm{~km}$, the beaches stretch almost a continuous strip.

The use of the sea coastal part and the beach is the main curative factor that attracts vacationers, it should be provided with a level of sanitary parameters. The identification of the marine area ecological state of the Western Crimea near high-rise construction zone was the study purpose.

Modern theoretical and applied researches to study problems of the Crimea coastal zones' ecological safety are carried out by scientists of the Marine Hydrophysical Institute V.A.

*Corresponding author: sapronovat@mail.ru 
Ivanov, Yu.N. Goryachkin, V.V. Fomin, V.F. Udovik (Goryachkin, 2010), design works in the coastal zone are carried out by the TsNTU "Inzhzashchita" under the guidance of M.N. Ryzhyi (2015).

\section{Materials and methods}

The development of coastal recreational zones is associated with the use of considerable space, and the tourism uncontrolled development causes damage to the environment: the intensive development of coastal recreational zones significantly changes the natural landscape, leads to pollution with their waste, pollution of the air as a result of the increase in the number of road transport.

The greatest damage to coastal waters is caused by local sources of pollution. The most vulnerable ones are the water areas of bays and gulfs with weak water exchange, which requires the development of measures to improve the ecological state of the sea coastal zone (Aibulatov, 2005).

During the research, the experimental (route inspection, sea water coastal sampling according to existing methods), analytical (analysis of selected samples by different chemical and physicochemical methods, sanitary-hygienic assessment of the environment under study), and the method of statistical generalization (determination of parameters zones of pollution of the coastal zone of the sea) were successfully used.

The condition of the coastal recreational zone ecosystem is determined through an assessment of its natural and technogenic factors and indicators (parameters). Such an ecosystem condition assessment is carried out on the basis of a criteria limited number that ensure a confident qualification of its condition in a joint examination. This requires a unified approach to assessing the state of both the ecosystem and its constituent components.

The territory of coastal recreational zones is a set of different functional zones, united by multiple connections into a complex dynamic system. Town-planning scheme for the construction of settlements is largely determined by the relief (the valleys of Belbek rivers (Lyubimovka village), Kacha (Orlovka village), Alma (Peschanoe village)).

The western coastal recreational zone of Crimea is an example of a linear type resort agglomeration. Currently, the planning structure of the Western Crimea settlements is in the process of formation. Due to the intensive construction of sanatorium, health resorts and recreational facilities, as well as spontaneously emerged areas of individual construction, individual settlements joined into a single urbanized strip. This phenomenon significantly worsens the quality of the habitat.

The territory under consideration is covered by a combined system for the removal of surface waters, a closed local stormwater network and open rain storms, located mainly in the health resorts and boarding houses. Pollution of surface runoff by heavy metals occurs during flushing with roadway plums.

Then, the surface runoff falls without preliminary purification into water bodies through the system of drainage trays and culverts.

In order to assess the ecological condition of water resources and the level of its disturbance in the coastal recreational zone of the Western Crimea, natural and analytical studies of the sea water quality in the coastal zone were conducted and the results of observations for 1998-2010 were processed. The results of the research are grouped in the following areas:

- level of pollution by the coastal drains;

- sanitary and hygienic characteristics of sea water for bathing.

To clarify the factors that formed the coastal zone ecological condition, the existing information on the ecological situation of the territory was analyzed. The maps of ecological and engineering-geological surveys were drawn up for some Western Crimea territories and 
settlements, with the following aspects: functional zoning of territories' development; density of recreational facilities development; objects (enterprises, facilities) operating on the TSO; organized and unorganized sources of pollutant emissions; discharge sources of sewage and sewage; maps of engineering-geological conditions. Full-scale geochemical investigations with water sampling and analysis in the laboratory using accredited methods were performed.

The A, B, C, D classes standards of the European Quality Movement for the resort cities "Blue Flag of Europe" were used, in order to assess the quality of wastewater treatment, the sea water. During the study, an experimental (route survey, sea water sampling, according to existing methods, analytical analysis of selected samples by various methods of chemical engineering, chemical and physicochemical methods, sanitary and hygienic assessment of the environment under study, zone of the sea) were used

\section{Results}

Sewage in the Western Crimea is fed to the Evpatoria, Saki and Kachin treatment facilities through a sewage pumping station system. After treatment, sewage is discharged into the sea through deep-water discharges at a distance of $1600 \mathrm{~m}$ from the shore (Evpatoria CBS), 1800 m - Saki CBS, 1250 m - Kachin CBS (Figure 1).

Table 1. Results of experimental studies of the coastal waters' quality of Crimea Western (in the area of releases) (August 1998-2010)*

\begin{tabular}{|c|c|c|c|c|c|c|c|c|c|c|c|c|c|}
\hline \multirow[t]{2}{*}{$\mathrm{N}$} & \multirow[t]{2}{*}{$\begin{array}{l}\text { Water } \\
\text { comp } \\
\text { ositio } \\
\mathrm{n} \\
\text { indica } \\
\text { tors }\end{array}$} & \multicolumn{3}{|c|}{$\begin{array}{l}\text { Pollutants in the } \\
\text { sea water in } \\
\text { Saki area CBS, } \\
\mathrm{mg} / \mathrm{dm} 3\end{array}$} & \multicolumn{3}{|c|}{$\begin{array}{l}\text { The content of } \\
\text { pollutants in the } \\
\text { sea water in } \\
\text { Saki area CBS, } \\
\mathrm{mg} / \mathrm{dm} 3\end{array}$} & \multicolumn{2}{|c|}{$\begin{array}{l}\text { The } \\
\text { content of } \\
\text { pollutants } \\
\text { in the } \\
\text { seawater } \\
\text { near the } \\
\text { Kachinsky } \\
\text { area CBS }\end{array}$} & \multirow[t]{2}{*}{$\begin{array}{l}\text { MP } \\
\text { C } \\
\mathrm{mg} / \\
\mathrm{dm} \\
3\end{array}$} & \multicolumn{3}{|c|}{$\begin{array}{l}\text { Exceeding the MPC } \\
\mathrm{C}, \mathrm{mg} / \mathrm{dm} 3 \\
\text { MPC } \\
\text { (n times) }\end{array}$} \\
\hline & & $\begin{array}{l}19 \\
98 \\
y\end{array}$ & $\begin{array}{l}200 \\
4 \\
y\end{array}$ & $\begin{array}{l}201 \\
0 \\
\mathrm{y}\end{array}$ & $\begin{array}{l}199 \\
8 \\
y\end{array}$ & $\begin{array}{l}200 \\
4 \\
y\end{array}$ & $\begin{array}{l}201 \\
0 \\
y\end{array}$ & $\begin{array}{l}199 \\
8 \\
y\end{array}$ & $\begin{array}{l}2010 \\
y\end{array}$ & & $\begin{array}{l}\text { Evpat } \\
\text { oria }\end{array}$ & $\begin{array}{l}\mathrm{Sa} \\
\mathrm{ks}\end{array}$ & $\begin{array}{l}\text { Kachin } \\
\text { sky }\end{array}$ \\
\hline 1 & $\begin{array}{l}\text { BOD } \\
\text { compl } \\
\text { et }\end{array}$ & - & $\begin{array}{l}17, \\
36\end{array}$ & \begin{tabular}{|l|}
17,4 \\
55
\end{tabular} & - & $\begin{array}{l}30, \\
6\end{array}$ & $\begin{array}{l}30, \\
6\end{array}$ & - & - & $\begin{array}{l}17,4 \\
6\end{array}$ & 0,99 & 1,7 & \\
\hline & BOD5 & $\begin{array}{l}8, \\
8\end{array}$ & - & - & $\begin{array}{l}19, \\
9\end{array}$ & & & 6,8 & 1,0 & 3,00 & 2,9 & 6,6 & 2,2 \\
\hline 2 & $\begin{array}{l}\text { Suspe } \\
\text { nded } \\
\text { substa } \\
\text { nces }\end{array}$ & 9 & $\begin{array}{l}14, \\
81\end{array}$ & $\begin{array}{l}14,9 \\
0\end{array}$ & 20 & $\begin{array}{l}30, \\
0\end{array}$ & $\begin{array}{l}30, \\
0\end{array}$ & 8,0 & 1,0 & 0,75 & 0,99 & 2,0 & 0,5 \\
\hline 3 & $\begin{array}{l}\text { Amm } \\
\text { onia } \\
\text { nitrog } \\
\text { en }\end{array}$ & $\begin{array}{l}2, \\
97\end{array}$ & $\begin{array}{l}31, \\
2\end{array}$ & $\begin{array}{l}31,1 \\
3\end{array}$ & $\begin{array}{l}22, \\
09\end{array}$ & $\begin{array}{l}13, \\
86\end{array}$ & $\begin{array}{l}13 \\
86\end{array}$ & 2,2 & 0,01 & 2,0 & 15,6 & $\begin{array}{l}11, \\
0\end{array}$ & 1,1 \\
\hline 4 & Nitrite & $\begin{array}{l}0, \\
07 \\
1\end{array}$ & $\begin{array}{l}6,6 \\
8\end{array}$ & $\begin{array}{l}6,73 \\
5\end{array}$ & $\begin{array}{l}0,4 \\
95\end{array}$ & $\begin{array}{l}2,3 \\
1\end{array}$ & $\begin{array}{l}2,3 \\
1\end{array}$ & $\begin{array}{l}0,0 \\
31\end{array}$ & $\begin{array}{l}0,00 \\
1\end{array}$ & 3,3 & 2,04 & 0,7 & 0,009 \\
\hline 5 & $\begin{array}{l}\text { Phosp } \\
\text { hates }\end{array}$ & - & 693 & $\begin{array}{l}642, \\
5\end{array}$ & - & $\begin{array}{l}7,6 \\
4\end{array}$ & $\begin{array}{l}7,6 \\
4\end{array}$ & & - & 3,5 & $\begin{array}{l}198 \\
\end{array}$ & 2,1 & - \\
\hline 6 & $\begin{array}{l}\text { Nitrat } \\
\text { es }\end{array}$ & $\begin{array}{l}1, \\
3\end{array}$ & $\begin{array}{l}0,8 \\
81 \\
\end{array}$ & $\begin{array}{l}0,89 \\
4\end{array}$ & 0,6 & $\begin{array}{l}10, \\
3\end{array}$ & $\begin{array}{l}10, \\
3\end{array}$ & 0,7 & $\mathrm{H} / \mathrm{O}$ & 45,0 & 0,01 & 0,2 & 0,015 \\
\hline 7 & $\begin{array}{l}\text { Petrol } \\
\text { eum }\end{array}$ & $\begin{array}{l}0, \\
02\end{array}$ & $\begin{array}{l}0,0 \\
18\end{array}$ & $\begin{array}{l}0,01 \\
79\end{array}$ & $\begin{array}{l}0,0 \\
8\end{array}$ & - & - & $\begin{array}{l}0,0 \\
2\end{array}$ & $\mathrm{H} / \mathrm{O}$ & 0,3 & 0,06 & 0,2 & 0,06 \\
\hline
\end{tabular}




\begin{tabular}{|l|l|l|l|l|l|l|l|l|l|l|l|l|l|}
\hline & $\begin{array}{l}\text { produ } \\
\text { cts }\end{array}$ & & & & & & & & & & & & \\
\hline 8 & Iron & $\begin{array}{l}0, \\
05\end{array}$ & $\begin{array}{l}0,0 \\
99\end{array}$ & $\begin{array}{l}0,09 \\
9\end{array}$ & $\begin{array}{l}0,0 \\
1\end{array}$ & - & - & $\begin{array}{l}0,0 \\
2\end{array}$ & - & 0,3 & 0,3 & 0,0 & 0,06 \\
\hline 9 & $\begin{array}{l}\text { Coppe } \\
\mathrm{r}\end{array}$ & - & $\begin{array}{l}0,0 \\
18\end{array}$ & $\begin{array}{l}0,01 \\
79\end{array}$ & - & - & - & - & - & 1,0 & 0,01 & - & - \\
\hline 10 & $\begin{array}{l}\text { Chro } \\
\text { mium }\end{array}$ & - & $\mathrm{H} / \mathrm{o}$ & $\mathrm{H} / \mathrm{o}$ & - & - & - & - & - & 0,05 & - & - & - \\
\hline 11 & SPAC & $\begin{array}{l}0, \\
04\end{array}$ & $\begin{array}{l}0,2 \\
02\end{array}$ & $\begin{array}{l}0,20 \\
6\end{array}$ & $\begin{array}{l}0,2 \\
47\end{array}$ & $\begin{array}{l}1,0 \\
6\end{array}$ & $\begin{array}{l}1,0 \\
6\end{array}$ & $\begin{array}{l}0,0 \\
25\end{array}$ & $\mathrm{H} / \mathrm{o}$ & 0,23 & 0,8 & 4,6 & 0,1 \\
\hline 12 & Zinc & - & $\begin{array}{l}0,0 \\
48\end{array}$ & $\begin{array}{l}0,04 \\
79\end{array}$ & - & - & - & - & - & - & 1 & - & - \\
\hline
\end{tabular}

Analysis of the study results showed that the sewerage networks of cities and towns in the coastal recreational zone of the Western Crimea have significant physical wear $(62-85 \%)$ and insufficient capacity, the sewage treatment system is created and operates without taking into account storm water.

It is established by (Ivanenko et al., 2011) in the period of rainfall precipitation anthropogenic pollution (household and industrial waste, oil products, fertilizers, etc.) coming from the entire catchment to the sea with surface runoff

\section{Discussion}

As a result of the natural and analytical studies conducted for the coastal recreational zone of the Western Crimea, zones of environmental disturbances in populated areas were identified (Table 2): pollution of the sea coastal zone by deepwater and emergency discharges (production of insufficiently treated sewage with CBS, emergency releases of sanatoriums, storm sewage); unsatisfactory technical condition of bank protection structures.

Due to the lack of storm sewerage development in the new construction zone of resort facilities, the surface runoff falls directly into the coastal zone of the sea, contaminating it with heavy metals, oil products, organic compounds.

In addition, there are local characteristics of both the formation and discharge of effluents.

There are no treatment facilities in the village Novofedorivka, so the natural pond is turned into a reservoir-settler of the village sewage.

Table 2. Violations of the marine waters ecological state in the coastal recreational zone of the Western Crimea

\begin{tabular}{|c|c|c|l|}
\hline $\begin{array}{c}\text { In a } \\
\text { settlement } \\
\text { s }\end{array}$ & $\begin{array}{c}\text { Category of } \\
\text { purification } \\
\text { grade }\end{array}$ & $\begin{array}{c}\text { Method of } \\
\text { sewage } \\
\text { treatment }\end{array}$ & \multicolumn{1}{c|}{$\begin{array}{c}\text { Violations of the marine waters' } \\
\text { ecological state }\end{array}$} \\
\hline $\begin{array}{c}\text { Lubovka } \\
\text { village }\end{array}$ & $\begin{array}{l}\text { Normally - } \\
\text { limited purified }\end{array}$ & $\begin{array}{c}\text { Mechanical } \\
\text { and } \\
\text { biological } \\
\text { ways }\end{array}$ & $\begin{array}{l}\text { - pollution of the sea coastal zone by } \\
\text { insufficiently purified (for biological } \\
\text { treatment) discharges; } \\
\text { - exceeding the maximum permissible } \\
\text { concentration limit for sea water } \\
\text { quality indicators BOD, BOD5, } \\
\text { suspended solids, ammonium } \\
\text { nitrogen; } \\
\text { - emergency condition of sludge } \\
\text { treatment facilities. }\end{array}$ \\
\hline
\end{tabular}




\begin{tabular}{|c|c|c|c|}
\hline $\begin{array}{c}\text { In a } \\
\text { settlement } \\
\text { s }\end{array}$ & $\begin{array}{l}\text { Category of } \\
\text { purification } \\
\text { grade }\end{array}$ & $\begin{array}{l}\text { Method of } \\
\text { sewage } \\
\text { treatment }\end{array}$ & $\begin{array}{l}\text { Violations of the marine waters' } \\
\text { ecological state }\end{array}$ \\
\hline $\begin{array}{l}\text { Orlovka } \\
\text { village }\end{array}$ & $\begin{array}{l}\text { Normally - } \\
\text { limited purified }\end{array}$ & $\begin{array}{l}\text { biological } \\
\text { way }\end{array}$ & $\begin{array}{l}\text { - pollution of the sea coastal zone by } \\
\text { insufficiently purified (for biological } \\
\text { treatment) discharges due to } \\
\text { insufficient capacity of the WWTP for } \\
\text { channeling recreational facilities; } \\
\text { - excess of MPC for sea water quality } \\
\text { indicators BOD5, suspended } \\
\text { substances, nitrites, phosphates, } \\
\text { ammonium nitrogen; } \\
\text { - the absence of the second (reserve) } \\
\text { collector from the SPS to the CBS. }\end{array}$ \\
\hline $\begin{array}{l}\text { Andreevka } \\
\text { village }\end{array}$ & $\begin{array}{l}\text { Normally - } \\
\text { limited purified }\end{array}$ & $\begin{array}{l}\text { biological } \\
\text { way }\end{array}$ & $\begin{array}{l}\text { - pollution of the sea coastal zone by } \\
\text { insufficiently purified (for biological } \\
\text { treatment) discharges in the } \\
\text { emergency condition of structures; } \\
\text { - discharge of insufficiently treated } \\
\text { sewage by the release of } 15 \text { l.m. from } \\
\text { the water's edge in the beach area; } \\
\text { - insufficient CBS capacity for } \\
\text { development of the recreation zone }\end{array}$ \\
\hline $\begin{array}{l}\text { Kacha } \\
\text { Town }\end{array}$ & $\begin{array}{l}\text { Normally - } \\
\text { limited purified }\end{array}$ & $\begin{array}{l}\text { biological } \\
\text { way }\end{array}$ & $\begin{array}{l}\text { - pollution of the sea coastal zone by } \\
\text { insufficiently purified (by biological } \\
\text { treatment) discharges } \\
\text { - the absence of the second (reserve) } \\
\text { collector from the SPS to the CBS. }\end{array}$ \\
\hline
\end{tabular}

The large number of organic substances entering in the pond of a given locality colormates a few natural drains in sand interlayer and limits the possibilities of filtration from the pond. This leads to its overflow and an increase in the level of groundwater and nearby area flooding. As a result, an emergency discharge through the trenches to the Black Sea is carried out annually, at the end of the holiday season.

An important source of bacterial pollution of the sea, as it was established by the authors, can be insufficiently purified sewage from sewage treatment plants located in Yevpatoria, Saki,. Nikolaevka, Peschanoe, Andreevka and Kacha town. The quality of water cleaning does not meet sanitary requirements (sewer networks are worn out, high accident rate of their work). Only in the Nikolaevka water from sewage treatment plants enter the fields, but not into the sea.

As a result of the pollution transfer by currents, the entire marine area is contaminated with ammonium nitrogen, nitrites, phosphates, and surfactants. It should be emphasized that the beach strip is also polluted.

The highest pollution levels are observed in the Yevpatoriya Sea Port. The content of suspended solids at the outlet from the WWTP is reduced by $90-95 \%$, BOD - by $80-85 \%$, COD by $80-98 \%$, etc. According to these indicators, the cleaned sewage of the WWTP of the Crimea West Coast complies with the norms for discharging substances from urban treatment facilities according to the "European Directive". At the same time, in addition to the normatively, clean waters that have already been cleared at sewage treatment plants (CBS), insufficiently purified water and water are discharged into the sea without purification. 
In general, the quality of sea water of the Western Crimea coast in terms of microbiological and physicochemical indicators (in terms of BOD5 MPC is exceeded in 2.26.6 times, in terms of Ammonium nitrogen in 1.1-15.6 times) can be attributed to class $\mathrm{C}$ (periodic pollution).

At the same time, the most promising class A water quality is located in areas with a minimum recreational load (Uglovoye village, Beregovoe village, Kacha village).

In general, the problems of ensuring the environmentally safe state of the Western Crimea marine waters require further research to prepare engineering and technical measures that, in the complex, will allow them to be solved in the current period and prevent future development

\section{Conclusion}

In accordance with the study objectives, the analysis of the sea waters ecological state of the Western Crimea coastal was made. It was found that the inadequate sewer networks coverage and structures, their unsatisfactory condition and insufficient capacities in the zone, contribute to the pollution of certain coastal territory sections and the sea by organic compounds, oil products, heavy metals new construction of resort facilities, unorganized surface runoff to the sea coastal zone. Justifying technical solutions to this problem, it is advisable to take into account that in order to maintain the coastal strip of the sea in an uncontaminated state, it is necessary to have a gap between the coastline and the boundary of the urbanization zone of 200-300 m.

\section{References}

1. Yu.N. Goryachkin, Current state of the Black Sea coast of the Crimea, Reports NAS of U, No. 10, 78-82 (2010)

2. M.N. Ryzhy, Problems of engineering protection of the Crimean sea coasts and ways of their solution in modern conditions Sevastopol, 13-15 (2015)

3. N.A. Aibulatov, Russia's activities in the coastal zone of the sea and the problems of ecology, Science, Moscow, 304 (2005)

4. T.A. Ivanenko, Ecological condition of big Yalta water resources Building and technogenic security, Crimea, Vol. 40 (2011) 